\title{
Simplified preparation of human arterial sections for PCR analysis of Chlamydia pneumoniae and human DNA
}

\author{
D Palfrey, P J Cook, J A Smythe, G Y H Lip, A V Hine
}

\begin{abstract}
Aims - To investigate multiple techniques for the preparation of solid tissue for polymerase chain reaction (PCR) analysis, and to identify the most simple techniques for routine use in the laboratory.

Methods - Techniques for the preparation of arterial tissue samples including homogenisation, ultrafiltration, and treatments involving proteinase $K$, Gene Clean ${ }^{\mathrm{TM}}$, lectin, and $\mathrm{Fe}^{3+}$ specific chelators were evaluated using the PCR to amplify both Chlamydia pneumoniae and human DNA.

Results-Treatment with either GeneClean or lectin and the $\mathrm{Fe}^{3+}$ specific chelator deferoxamine mesylate removed PCR inhibitors from tissue homogenates. Homogenisation followed by GeneClean treatment resulted in the amplification of $C$ pneumoniae DNA from within a section of atherosclerotic carotid artery, implying that $C$ pneumoniae elementary bodies had been disrupted. In eight further clinical samples from patients not known to have $C$ pneumoniae infection, human DNA was amplified and no cross contamination was observed between samples. These samples contained no evidence of $C$ pneumoniae by PCR.
\end{abstract}

Pharmaceutical Sciences Research Institute, Aston University, Aston Triangle, Birmingham B4 7ET, UK

D Palfrey

J A Smythe

A V Hine

Department of

Respiratory Medicine, Birmingham

Heartlands Hospital,

Bordesley Green East, Birmingham B9 5SS, UK

P J Cook

University

Department of

Medicine, City

Hospital, Dudley

Road, Birmingham

B18 7QH, UK

G Y H Lip

Correspondence to: Dr Hine.

email: a.v.hine@aston.ac.uk

Accepted 27 May 1999

species of Chlamydia have been scribed, of which the most prevalent is Chlamydia pneumoniae. Many studies have shown immunohistological and polymerase chain reaction (PCR) evidence of this infection in atherosclerotic coronary, ${ }^{1-4}$ carotid, $^{5-7}$ and peripheral arteries. ${ }^{8}$ In contrast, however, Weiss et al found no evidence of $C$ pneumoniae by PCR or culture in 57 of 58 percutaneous coronary atherectomy specimens, or by electron microscopy in all of 22 specimens. ${ }^{9}$ In a study from Australia, chlamydial DNA was undetectable by PCR in 49 atherosclerotic carotid and coronary artery samples from postmortems. ${ }^{10}$ Moreover, given the demonstration by PCR of $C$ pneumoniae DNA in peripheral blood mononuclear cells of patients with coronary heart disease and healthy middle aged blood donors, ${ }^{11}$ there is a lingering suspicion that this organism merely contaminates preformed atheromatous material.

More studies based on PCR are needed, but there are still a number of difficulties that must be overcome before these methods can be adopted widely for routine testing. ${ }^{12}$ Current methods of human tissue sample preparation for amplification both of human and microbial DNA are problematic because Taq polymerase is readily inhibited by tissues. These problems are compounded by the unique life cycle of the chlamydiae, ${ }^{13}$ the first stage of which, the elementary body, is highly condensed, owing to extensive disulphide crosslinking of cysteine rich envelope proteins, and must be lysed (for example, by incubation with detergents) to release chlamydial DNA. In itself, lysis of elementary bodies runs a risk of reducing DNA template activity.

There are several preparations available for PCR based analysis of $C$ pneumoniae in solid tissue, but most are time consuming, labour intensive, or both. For example, whereas some investigators simply homogenise tissue and then treat the homogenate with detergent/ proteinase $\mathrm{K}$ and heat, ${ }^{9}$ others also perform phenol/chloroform extractions and ethanol precipitation, ${ }^{414}$ or cetyltrimethylammonium bromide (CTAB) based purification of the nucleic acids before PCR. ${ }^{7}$ Alternatively, samples may be homogenised directly in buffer containing detergent and $\mathrm{RNase}^{2315}$ and the resulting nucleic acids purified by conventional means ${ }^{15}$ or by using commercial ion exchange based resins. $^{23}$

By examining multiple preparation techniques, each designed to eliminate known classes of PCR inhibitors, the aim of our study was to compare methods of sample preparation to simplify and improve PCR based amplification from solid tissue.

\section{Methods}

TECHNIQUES FOR TISSUE PREPARATION

All arterial sections were stored at $-20^{\circ} \mathrm{C}$. A tissue sample $\left(\sim 3 \mathrm{~mm}^{2}\right)$ containing both arterial wall and atheromatous plaque material was dissected from each section, which was returned immediately to $-20^{\circ} \mathrm{C}$. The sample was then homogenised. Tissue dissections were performed under sterile conditions, using sterile, disposable implements. All sample preparations were performed in a laboratory separate to that in which the PCRs were performed. Filter tips for autopipettes were used throughout. 
Homogenisations were performed in sterile microcentrifuge tubes using sterile, disposable pestles (Sigma, Poole, Dorset, UK), either at room temperature in $80 \mu \mathrm{l}$ of $1 \times$ Perkin Elmer PCR buffer (PE/Applied Biosystems, Warrington, $\mathrm{UK}$ ) (PE buffer: $10 \mathrm{mM}$ Tris $/ \mathrm{HCl}$, $\mathrm{pH} 8.3,50 \mathrm{mM} \mathrm{KCl}, 1.5 \mathrm{mM} \mathrm{MgCl}, 0.001 \%$ gelatin) or dry, over liquid nitrogen. Homogenised samples were then treated according to one or more of the following techniques.

GeneClean $^{\mathrm{TM}}$ is a commercial preparation that purifies nucleic acid of proteins and other contaminants. In essence, a crude mixture containing DNA is added to fine glass beads under high salt conditions. Under these conditions, nucleic acids adhere to the glass beads, whereas contaminants such as proteins, carbohydrates, and ions do not. The beads are washed in a proprietary mixture of salts and ethanol to remove unbound, contaminating material. DNA is then eluted from the beads by a water wash because, under low salt conditions, nucleic acids do not adhere to the glass beads. GeneClean treatments were performed according to the manufacturer's instructions (Anachem, Luton, UK).

Proteinase $\mathrm{K}$ was dissolved in $1 \times \mathrm{PE}$ buffer and added to homogenised samples to a final concentration of $10 \mu \mathrm{g} / \mu \mathrm{l}$. Triton X-100 was added to a concentration of $0.5 \%$ and the mixture was incubated at $55^{\circ} \mathrm{C}$ for one hour. The enzyme was inactivated by heating to $95^{\circ} \mathrm{C}$ for five minutes. Samples were microfuged at $14000 \times g$ for 30 seconds and the supernatant removed for use in PCR assays.

The $\mathrm{Fe}^{3+}$ specific chelators ethylenediamine$\mathrm{N}, \mathrm{N}^{\prime}$-diacetic acid (EDDA) and deferoxamine mesylate (Sigma) were dissolved in $0.1 \mathrm{M}$ $\mathrm{NaOH}$ to final concentrations of $10 \mathrm{mg} / \mathrm{ml}$. Stock solutions were then added to the PCR mixtures, to final concentrations of $0.2 \mathrm{mg} / \mathrm{ml}$, before cycling.

The lectin concanavalin A (Sigma) was dissolved in $1 \times \mathrm{PE}$ buffer and added to the tissue homogenate to a concentration of $30 \mathrm{ng} / \mu \mathrm{l}$. The mixture was incubated on ice for $30 \mathrm{~min}$ utes, with vortexing at five minute intervals. Samples were microfuged at $14000 \times g$ for 30 seconds and the supernatant removed for use in PCR assays.

For ultrafiltration, $15 \mu \mathrm{l}$ of treated homogenate was processed through a Microcon ${ }^{\circledR}-30$ microconcentrator (Millipore, Watford, UK) and the DNA was recovered from the upper reservoir according to manufacturer's instructions, in $10 \mu$ l sterile distilled $\mathrm{H}_{2} \mathrm{O}$.

\section{PCR AMPLIFICATIONS}

PCRs $(50 \mu \mathrm{l})$ were performed in either $1 \times \mathrm{PE}$ buffer or $1 \times \mathrm{AB}$ buffer IV (Advanced Biotechnologies, Epsom, UK) (AB buffer IV: $75 \mathrm{mM}$ Tris/HCl, pH 9.0, $20 \mathrm{mM}\left(\mathrm{NH}_{4}\right)_{2} \mathrm{SO}_{4}, 0.01 \%$ Tween), with additional components as described, and either $1 \mu \mathrm{l}$ of sterile distilled $\mathrm{H}_{2} \mathrm{O}$ (negative controls) or $1 \mu \mathrm{l}$ of template DNA, prepared as described. Reactions were cycled 30 times for 30 seconds at $95^{\circ} \mathrm{C}, 30$ seconds at $55^{\circ} \mathrm{C}$, and 60 seconds at $72^{\circ} \mathrm{C}$, unless stated otherwise. After amplification, 20\% of each reaction was examined by electrophoresis on a $2 \%$ agarose gel.

OPTIMISATION OF PCR AMPLIFICATIONS

PCR amplifications were optimised according to the following strategy:

Buffer selection $\rightarrow \mathrm{Mg}^{2+}$ concentration $\rightarrow$ Quantity of Taq DNA polymerase $\rightarrow$ dNTP concentration $\rightarrow$ Primer concentration

MATERIALS

Genomic DNA was purified from $C$ pneumoniae elementary bodies by Dr A Cunningham (University of Southampton, UK) and from $C$ pssitaci by Dr C Storey (University of Manchester, UK). Taq DNA polymerase was obtained from Perkin Elmer (PE/Applied Biosystems).

Oligonucleotide primers: CP1, 5'-GTGATC TGTAACGTATCG-3'; CP2， 5'-AGTAGA CAATGCTGTGGC-3'; H1， 5'-ACTCCT CGTTGTTTACCC-3'; and H2, 5'-TTC TCAGGATCCACATGC-3' were synthesised on a Beckman Oligo 1000 DNA synthesiser or purchased from Applied Biosystems. Primers CP1 and CP2 anneal to the major outer membrane protein (MOMP) gene of $C$ pneumoniae strain IOL207, as sequenced by Carter and colleagues $^{16}$ (Genbank accession number M64064). Primers CP1 and CP2 correspond to bases $670-687$ and the reverse complement of bases 970-987 of sequence M64064, respectively. Primers $\mathrm{H} 1$ and $\mathrm{H} 2$ anneal to exon 2 of the human $\varepsilon$-globin gene, which is contained within the human $\beta$-globin region of chromosome 11 (Genbank accession number U01317). Primer H1 corresponds to the first 18 bases (19755-19772, U01317) and primer $\mathrm{H} 2$ corresponds to the reverse complement of bases 198-215 (19953-19970, U01317) of this exon.

Atheromatous plaque material was collected between September 1995 and September 1996. Patients were recruited after selection for carotid, coronary, or peripheral endarterectomy (for established atheromatous disease) by consultant vascular or cardiothoracic surgeons at the City Hospital, Birmingham and Walsgrave Hospital, Coventry. Exclusion criteria were known or suspected immunodeficiency or hepatitis B viral infection, or apparent risk of acquiring serum hepatitis or human immunodeficiency virus infection. All patients gave informed consent and the study was approved by the district ethics committee.

\section{Results}

DEVELOPMENT OF PCR ASSAYS

Two PCR assays were developed to test the methods of sample preparation. One amplified hypervariable region IV of the $C$ pneumoniae MOMP gene and the second was a simple amplification of human DNA, encompassing exon 2 of the human $\varepsilon$-globin gene. The first PCR is technically more demanding because of the need to lyse $C$ pneumoniae elementary bodies. Conditions were therefore optimised for this amplification using the strategy outlined above, with purified $C$ pneumoniae genomic DNA as a template. 


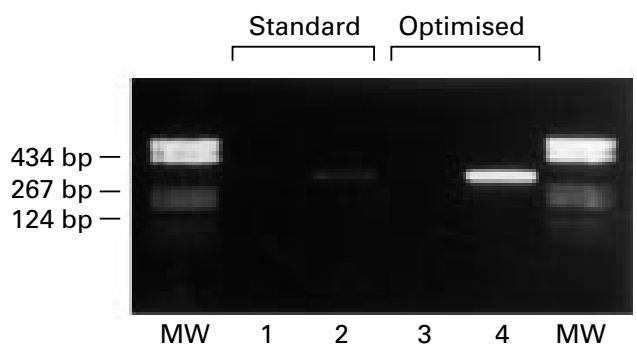

Figure 1 Optimisation of Chlamydia pneumoniae PCR. PCR amplifications of $\mathrm{H}_{2} \mathrm{O}$ (negative controls) and $C$ pneumoniae genomic DNA were performed with primers $C P 1$ and $C P 2$ as described under standard $(1 \times P E$ buffer, $100 \mu M d N T P s, 0.4 \mu M$ primers, 2 U Taq DNA polymerase) or optimised ( $1 \times A B$ buffer IV, $100 \mu \mathrm{M}$ dNTPs, $0.6 \mu M$ primers, 4 U Taq DNA polymerase) conditions, as indicated. Lane 1, negative control; lane 2, $C$ pneumoniae amplification; lane 3, negative control; lane 4, C pneumoniae amplification. MW, molecular weight marker (1 $\mu \mathrm{g}$ of a pBR322/HaeIII digest (Sigma)).

Amplification in a standard potassium containing buffer (Perkin Elmer) was compared with that in an ammonium sulphate containing buffer (Advanced Biotechnologies). Each buffer system was used with $\mathrm{MgCl}_{2}$ at concentrations of $1.5 \mathrm{mM}, 2.0 \mathrm{mM}, 2.5 \mathrm{mM}$, and $3.0 \mathrm{mM}$. No appreciable difference was noted between the different magnesium concentrations, but amplification in the ammonium sulphate containing buffer gave a consistently greater yield of PCR product. The ammonium sulphate containing buffer with $1.5 \mathrm{mM} \mathrm{MgCl}_{2}$ was therefore used in subsequent analyses.

Using this buffer system, the quantity of Taq DNA polymerase was optimised. PCR reactions with $1,2,3,4$, and $5 \mathrm{U}$ of enzyme/ reaction were performed. A great increase in product yield between 1 and $2 \mathrm{U}$ and a minimal further increase between 2 and $4 \mathrm{U}$ was observed. Therefore, $4 \mathrm{U}$ of Taq DNA polymerase were used during the remaining optimisation reactions.

The nucleotide concentration was then optimised: dNTP concentrations of 20, 50, 100, 150 , and $200 \mu \mathrm{M}$ were tested. A large increase in PCR product yield was observed between 20 and $100 \mu \mathrm{M}$ dNTPs, but no further increase in yield was observed above this point. A concentration of $100 \mu \mathrm{M}$ dNTPs was therefore used for future assays.

Primer concentrations between $0.2 \mu \mathrm{M}$ and $2 \mu \mathrm{M}$ in $0.2 \mu \mathrm{M}$ stages were then examined. Amplicon yield plateaued at a concentration of $0.6 \mu \mathrm{M}$ of primers. Consequently, this concentration was used. Finally, the optimum annealing temperature was investigated.

Under the optimised conditions, PCRs with annealing temperatures of $45^{\circ} \mathrm{C}, 50^{\circ} \mathrm{C}$, and $55^{\circ} \mathrm{C}$ were examined. Increasing temperature gave no diminution of product yield. The highest temperature $\left(55^{\circ} \mathrm{C}\right)$ was therefore used in subsequent analyses. Figure 1 shows that a significant increase in amplicon yield was achieved.

Because there is appreciable homology between the MOMP genes of $C$ pneumoniae and $C$ psittaci, ${ }^{17}$ a PCR under the optimised conditions was performed using purified $C$ psittaci DNA as a template. No amplification was observed (data not shown).
TECHNIQUES FOR TISSUE PREPARATION

Tissue preparation was evaluated initially using a single source of tissue. A section of atherosclerotic carotid artery was obtained by surgical endarterectomy in a patient with known carotid stenosis. Several preparative techniques were examined, to include one or more of the following: homogenisation, proteinase $\mathrm{K}$ treatment, GeneClean treatment, ultrafiltration, and the effects of lectin and $\mathrm{Fe}^{3+}$ specific chelators.

Initially, a tissue sample was homogenised at room temperature in $1 \times \mathrm{PE}$ buffer (sample 1 ). A $10 \mu \mathrm{l}$ aliquot of this homogenate was then purified by GeneClean (sample 2). As a comparison, a $10 \mu \mathrm{l}$ aliquot of the homogenate was treated with proteinase $\mathrm{K}$ (sample 3 ). Finally, a $5 \mu$ aliquot of sample 3 was treated with GeneClean (sample 4). Each sample was then used as a template in three PCRs: amplification of the human $\varepsilon$-globin gene; amplification of the $C$ pneumoniae MOMP gene; and a repeat of the $C$ pneumoniae amplification, "spiked" with purified genomic $C$ pneumoniae DNA (fig 2A). This last amplification served as a control, to examine the effectiveness of the preparative method in eliminating PCR inhibitors in the event that the sample contained no $C$ pneumoniae DNA.

As illustrated in fig 2A, no specific DNA product ( $317 \mathrm{bp}$ for the $C$ pneumoniae amplicon and $215 \mathrm{bp}$ for the human amplicon) was amplified from the untreated homogenate in any reaction. In contrast, positive, specific amplifications were seen from samples 2, 3, and 4 in all PCRs. However, the yield of PCR product was greatest from the template prepared by homogenisation and GeneClean (sample 2). Therefore, this preparation technique was used in subsequent assays. In addition to the specific amplicon, small DNA fragments $(<100 \mathrm{bp})$ were amplified in reactions that had been spiked with $C$ pneumoniae genomic DNA and from the optimal sample preparation of the tissue sample (sample 2). Because the yield of these small products is very low in the presence of the specific amplicon, we suggest that they arise from a secondary priming event on $C$ pneumoniae DNA, which occurs when specific amplification is impaired.

The chosen technique of homogenisation followed by GeneClean treatment was compared with alternative strategies. A fresh sample of tissue was homogenised as before and a $5 \mu \mathrm{l}$ aliquot of the homogenate was treated with GeneClean (sample 5). Further $5 \mu \mathrm{l}$ aliquots were treated with lectin alone (sample 6); lectin + EDDA (sample 7); lectin + deferoxamine mesylate (sample 8); lectin + ultrafiltration (sample 9); lectin + proteinase K (sample 10); lectin + proteinase $\mathrm{K}+$ EDDA (sample 11); lectin + proteinase $\mathrm{K}+$ deferoxamine mesylate (sample 12); and lectin + proteinase $\mathrm{K}+$ ultrafiltration (sample 13). No PCR products were obtained from any of the amplifications of samples 6 and 9-13 (data not shown), indicating that the treatments used to generate these samples had failed to remove PCR inhibitors. However, 


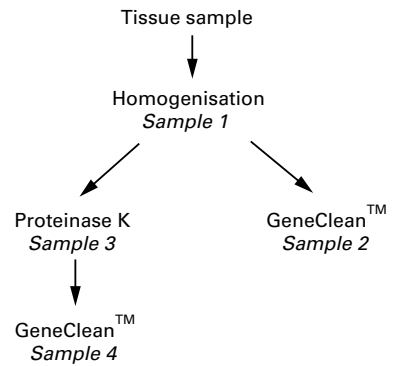

B

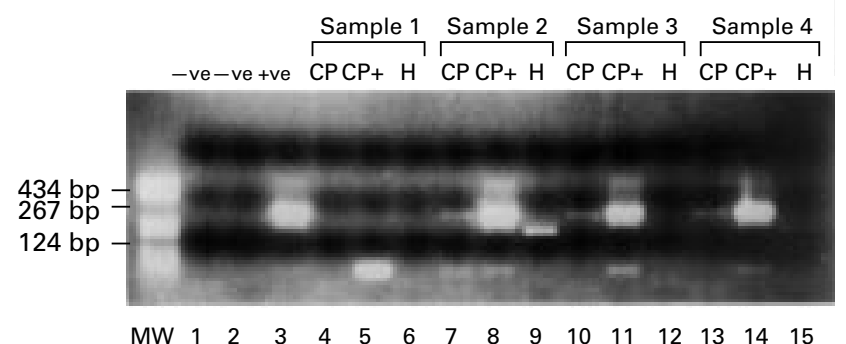

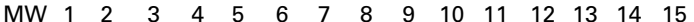
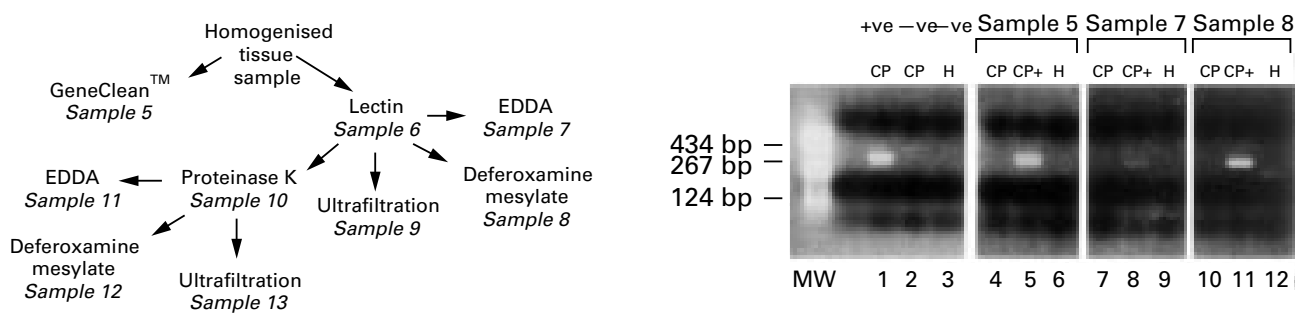

Figure 2 Summary of tissue preparation methods and their effectiveness for PCR amplifications. Tissue samples were prepared by homogenisation and supplementary treatments as indicated. Aliquots $(1 \mu \mathrm{l})$ of the prepared tissue samples were subjected to PCRs of the human E-globin gene $(H)$; the Chlamydia pneumoniae major outer membrane protein (MOMP) gene (CP); and the $C$ pneumoniae MOMP gene, in the presence of $C$ pneumoniae genomic DNA (CP+) as indicated. $M W$, molecular weight marker; -ve, control in which $1 \mu l \mathrm{H}_{2} \mathrm{O}$ replaced the prepared tissue sample; +ve, control in which $1 \mu l C$ pneumoniae genomic DNA replaced the prepared tissue sample. (A) Preparation methods and PCR analyses of samples 1-4; (B) preparation methods of samples 5-13 and PCR analyses of samples 5, 7, and 8.

successful amplifications from samples 5, 7, and 8 were obtained (fig 2B). Although no native chlamydial DNA was detected in any of these samples, chlamydial DNA was successfully amplified in the spiked reactions, with a yield of: sample $5>$ sample $8>$ sample 7 .

Collectively, these results demonstrate that either GeneClean or combined lectin/chelator treatment of the crude homogenate is sufficient to remove PCR inhibitors. Because the GeneClean treatment gave the highest yield of product in the spiked reaction and was shown to disrupt $C$ pneumoniae elementary bodies (fig $2 \mathrm{~A})$, this method was used for future analyses. The lack of amplification of native chlamydial DNA in the second analysis (fig 2B) suggests either that this original tissue sample contained no $C$ pneumoniae, or that the PCR reaction was insufficiently sensitive on this occasion.

PCR ANALYSIS OF CLINICAL SAMPLES

The sample preparation technique of tissue homogenisation followed by GeneClean treatment was applied to clinical samples from patients $\mathrm{A}-\mathrm{H}$, who were not known to be infected with $C$ pneumoniae. Tissue samples were homogenised dry over liquid nitrogen and were then suspended in $80 \mu \mathrm{l} 1 \times \mathrm{PE}$ buffer and purified using a GeneClean Spin $\mathrm{Kit}^{\mathrm{TM}}$ (Anachem). Dry homogenisation and the GeneClean Spin Kit were introduced to minimise the potential for cross contamination between samples, whereas treatment of the entire homogenate was performed to improve the yield of template DNA. To monitor potential cross contamination, a blank homo- genisation/purification containing only $1 \times \mathrm{PE}$ buffer was performed between that of each tissue sample. Each sample was then used as a template both for the $C$ pneumoniae PCR and for PCR of the human $\varepsilon$-globin gene. No $C$ pneumoniae amplicon resulted from any of the samples (data not shown). However, successful amplification of human DNA was seen for all tissue samples (fig 3), confirming that tissue homogenisation followed by GeneClean treatment is an effective preparation of solid tissue for PCR.
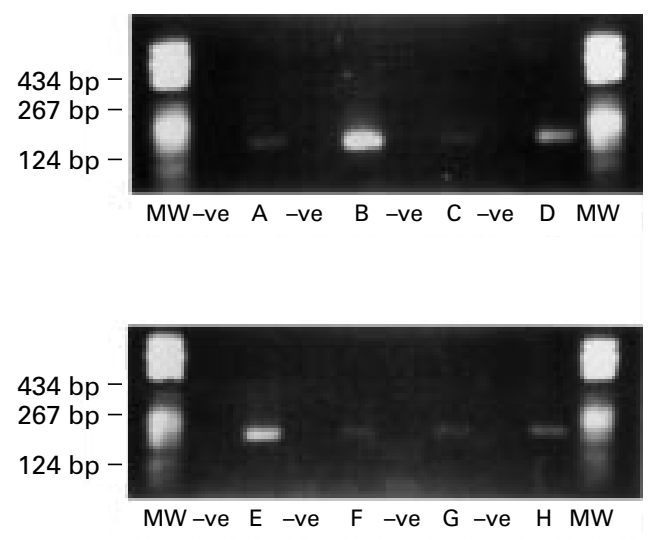

Figure 3 PCR amplification of human genomic DNA from tissue samples and blank preparations. Tissue samples $A-H$ and interspersed blank aliquots of buffer were prepared by homogenisation and GeneClean ${ }^{\mathrm{TM}}$ treatment. PCRs of the human E-globin gene were performed on $1 \mu \mathrm{l}$ aliquots of each sample as indicated. -ve, interspersed blank preparations; $M W$, molecular weight marker. 


\section{Discussion}

Chlamydia pneumoniae is even more difficult to culture than the other chlamydiae, so epidemiological evidence relating to it derives mainly from serological studies. ${ }^{18}$ In general, such studies have supported the view that $C$ pneumoniae infection occurs throughout the world, in both affluent and deprived communities, ${ }^{19}{ }^{20}$ in some of which it has been endemic at least since the late 1950 s. ${ }^{21}$ Chlamydia pneumoniae is a common respiratory pathogen in children as well as adults, ${ }^{22}{ }^{23}$ and persistent asymptomatic infection also appears to be common.

Chronic coronary artery disease and acute myocardial infarction have been associated with serological evidence of $C$ pneumoniae infection in many studies, ${ }^{24-30}$ and other studies have demonstrated serological associations with cerebrovascular disease ${ }^{3132}$ and systemic hypertension. ${ }^{33}$ In particular, antibodies against the $40,54,60,75$, and $98 \mathrm{kDa}$ outer membrane protein antigens of $C$ pneumoniae appear to be associated strongly with atherosclerosis, implying that they may be virulence factors. ${ }^{34}$ Serological evidence of previous $C$ pneumoniae infection is also associated with a proatherogenic serum cholesterol profile. ${ }^{35}$ Chlamydia pneumoniae has also been cultured from atherosclerotic material, ${ }^{36}{ }^{37}$ and has been demonstrated by immunohistochemistry in three cell types known to be important in atherogenesis, namely: endothelial cells, macrophages, and smooth muscle cells, ${ }^{38}$ all of which support $C$ pneumoniae growth in vitro. $^{39-41}$ In animal models, chlamydiae disseminate at an early stage to peripheral blood mononuclear cells, spleen, and peritoneal macrophages, ${ }^{42}{ }^{43}$ where they multiply. ${ }^{44}$ Using PCR and immunocytochemistry, $C$ pneumoniae has been shown to spread preferentially to cardiovascular tissue, ${ }^{45}$ where infection is followed by arterial lesions that resemble atherosclerosis. ${ }^{46-48}$ In cultured human endothelial cells, enhanced procoagulant (tissue factor) activity is also observed. ${ }^{49}$

This organism remains difficult to grow in the laboratory, and the usefulness of current culture and identification methods is limited by their sensitivity and specificity. Serology (principally micro-immunofluorescence) is still used widely, but crossreactions are reported between $C$ pneumoniae and other chlamydiae, particularly $C$ psittaci. ${ }^{50}$ Crossreactions have also been reported with Mycoplasma pneumoniae, owing to contamination of a commercial $C$ pneumoniae antigen preparation. ${ }^{51} 52$ Enzyme immunoassays have been developed for IgG and IgA antibodies to $C$ pneumoniae, but there is no indication that their sensitivity and specificity are superior to those of microimmunofluorescence. ${ }^{53}$ Moreover, concentrations of antichlamydial IgG, IgA, and IgM antibodies measured in atherosclerotic lesions by micro-immunofluorescence may show no correlation with direct detection by PCR. ${ }^{54} 55$

PCR of $C$ pneumoniae can detect $10^{-16} \mathrm{~g}$ of DNA, approximately equivalent to one chlamydial elementary body. It has been combined with enzyme immunoassay, and this combined test (PCR-EIA) used to screen throat swab and bronchoalveolar lavage specimens for $C$ pneumoniae. ${ }^{5657} \mathrm{~A}$ two stage PCR has also been described, which detects $C$ psittaci as well as $C$ pneumoniae in the first stage, but amplifies only $C$ pneumoniae DNA in the second stage. ${ }^{58}$

In our study, we have described two simple techniques for the preparation of solid tissue for PCR analysis. One, homogenisation followed by GeneClean treatment, has been performed on several tissue samples. The lack of contamination in blank samples suggests that this method is not prone to cross contamination. As an alternative, we have also described the preparation of tissue samples by homogenisation, followed by treatment with the $\mathrm{Fe}^{3+}$ specific chelator deferoxamine mesylate.

In addition, we have developed an optimised PCR for the MOMP gene of $C$ pneumoniae and demonstrated amplification of $C$ pneumoniae DNA from a clinical sample. This result implies that our combined procedure of homogenisation and GeneClean treatment lyses $C$ pneumoniae elementary bodies effectively. Interestingly, however, no $C$ pneumoniae DNA was detected in a second sample of the same tissue. Although this result may be an artefact caused by insufficient sensitivity of the PCR reaction, it might also arise from patchy localisation of $C$ pneumoniae within the arterial wall (analogous to localised bacterial colonies on the surface of an agar plate). Such a distribution of this organism would necessarily result in sporadic PCR results, because only some samples of the tissue would contain $C$ pneumoniae DNA. Previous sporadic amplifications of $C$ pneumoniae DNA from different sections of the same atherosclerotic lesion have been rationalised similarly. ${ }^{36}$ No $C$ pneumoniae DNA was amplified from clinical tissue samples A-H. This might have resulted either from the absence of $C$ pneumoniae DNA in those samples or from insufficient sensitivity of the PCR reaction. However, in the context of previous PCR based studies, ${ }^{9}{ }^{10}$ failure to detect $C$ pneumoniae in only eight atheromatous plaques is unsurprising. The successful amplification of human DNA from all clinical samples demonstrates that tissue homogenisation followed by GeneClean treatment is an effective preparation of solid tissue for PCR.

This work was supported by a grant from Zeneca Pharmaceuticals (GYHL) and by the Pharmaceutical Sciences Institute, Aston University (AVH). We thank Mr SH Silverman at the City Hospital and many of the consultant surgeons at Walsgrave Hospital for the collection of tissue specimens and Drs A Cunningham (University of Southampton) and C Storey (University of Manchester) for their generous donation of chalmydial DNAs.

1 Shor A, Kuo CC, Patton DL. Detection of Chlamydia pneumoniae in coronary arterial fatty streaks and atheromatous plaques. S Afr Med F 1992;82:158-61.

2 Kuo CC, Grayston JT, Campbell LA, et al. Chlamydia pneumoniae (TWAR) in coronary arteries of young adults (15-34 years old). Proc Natl Acad Sci USA 1995;92:691114.

3 Campbell LA, O'Brien ER, Cappuccio AL, et al. Detection of Chlamydia pneumoniae TWAR in human coronary

4 Ong G, Thomas BJ, Mansfield AO, et al. Detection and widespread distribution of Chlamydia pneumoniae in the videspread distribution of Chstem and its possible implications. F Clin Pathol 1996;49:102-6. 
5 Grayston JT, Kuo CC, Coulson AS, et al. Chlamydia pneumoniae (TWAR) in atherosclerosis of the carotid artery. Circulation 1995:92:3397-400.

6 Muhlestein JB, Hammond EH, Carlquist JF, et al. Increased incidence of Chlamydia species within the coronary arteries of patients with symptomatic atherosclerotic versus other forms of cardiovascular disease. $\mathcal{F} \mathrm{Am}$ Coll Cardiol 1996;27:1555-61.

7 Maass M, Krause E, Engel PM, et al. Endovascular presence of Chlamydia pneumoniae in patients with hemodynami-
cally effective carotid artery stenosis. Angiology 1997;48: 699-706.

8 Kuo CC, Coulson AS, Campbell LA, et al. Detection of Chlamydia pneumoniae in atherosclerotic plaques in the walls of arteries of lower extremities from patients undergoing bypass operation for arterial obstruction. $\mathcal{f}$ Vasc Surg 1997;26:29-31.

9 Weiss SM, Roblin PM, Gaydos CA, et al. Failure to detect Chlamydia pneumoniae in coronary atheromas of patients Chlamydia pneumoniae in coronary atheromas of patients
undergoing atherectomy. F Infect Dis 1996;173:957-62.

10 Paterson DL, Hall J, Rasmussen SJ, et al. Failure to detect Chlamydia pneumoniae in atherosclerotic plaques of AusChlamydia pneumoniae in atherosclerotic plac

11 Boman J, Soderberg S, Forsberg J, et al. High prevalence of Chlamydia pneumoniae DNA in peripheral blood mononuclear cells in patients with cardiovascular disease and in middle-aged blood donors. F Infect Dis 1998;178:274-7.

12 Garcia de Lomas J, Navarro D. New directions in diagnostics. Pediatr Infect Dis 7 1997;16(suppl 3):S43-8.

13 Moulder J. Interaction of chlamydiae and host cells in vitro. Microbiol Rev 1991;55:143-90.

14 Blasi F, Denti F, Erba M, et al. Detection of Chlamydia pneumoniae but not Helicobacter pylori in atherosclerotic plaques of aortic aneurysms. F Clin Microbiol 1996;34: plaques $2766-9$.

15 Kuo CC, Shor A Campbell LA, et al. Demonstration of Chlamydia pneumoniae in atherosclerotic lesions of coronary arteries. F Infect Dis 1993;167:841-9.

16 Carter MW, Al-Mahdawi SAH, Giles IG, et al. Nucleotide sequence and taxonomic value of the major outer sequence and taxonomic value of the major outer membrane protein gene of Chlamydia
207. F Gen Microbiol 1991;137:465-75.

17 Kuo CC, Jackson LA, Campbell LA, et al. Chlamydia pneumoniae (TWAR). Clin Microbiol Rev 1995;8:451-61.

18 Wang SP, Grayston JT. Micro-immunofluorescence serological studies with the TWAR organism. In: Oriel JD Ridgway GL, Schachter J, et al, eds. Chlamydial infections. Cambridge: Cambridge University Press, 1986:329-32.

19 Kleemola M, Saikku P, Visakorpi R, et al. Epidemics of pneumonia caused by TWAR, a new Chlamydia organism, in military trainees in Finland. F Infect Dis 1988;157:230-6.

20 Forsey T, Darougar S, Treharne JD, et al. Prevalence in human beings of antibodies to chlamydia IOL-207, an atypical strain of chlamydia. F Infect 1986;12:145-52.

21 Karvonen $M$, Tuomilehto J, Naukkarinen $A$, et al. The prevalence and regional distribution of antibodies against Chlamydia pneumoniae (strain TWAR) in Finland in 1958. Int f Epidemiol 1992;21:391-8.

22 Normann E, Gnarpe J, Gnarpe H, et al. Chlamydia pneumoniae in children with acute respiratory tract infections. Acta Paediar

23 Falck G, Heyman L, Gnarpe J, et al. Chlamydia pneumoniae and chronic pharyngitis. Scand $\mathcal{F}$ Infect Dis 1995;27:17982.

24 Saikku P, Leinonen M, Mattila KJ, et al. Serologic evidence of an association of a novel chlamydia, TWAR, with chronic coronary heart disease and acute myocardial infarction. Lancet 1988;II:983-6.

25 Thom DH, Grayston JT, Siscovick DS, et al. Association of prior infection with Chlamydia pneumoniae and angiographically demonstrated coronary artery disease. $7 A M A$ 1992;268:68-72.

26 Puolakkainen M, Kuo CC, Shor A, et al. Serological response to Chlamydia pneumoniae in adults with coronary arterial fatty streaks and fibrolipid plaques. 7 Clin Microbiol 1993;31:2212-14.

27 Cook PJ, Lip GYH, Beevers DG, et al. Chlamydia pneumoniae and acute arterial thrombotic disease. Circulation niae and acute

28 Dahlen GH, Boman J, Birgander LS, et al. Lp(a) lipoprotein, IgG, IgA and IgM antibodies to Chlamydia pneumoniae and HLA class II genotype in early coronary artery disease. Atherosclerosis 1995;114:165-74.

29 Mendall MA, Carrington D, Strachan D, et al. Chlamydia pneumoniae: risk factors for seropositivity and association with coronary heart disease. $\mathcal{F}$ Infect 1995;30:121-8.

30 Thomas GN, Scheel O, Koehler AP, et al. Respiratory chlamydial infections in a Hong Kong teaching hospital and association with coronary heart disease. Scand $\mathcal{F}$ Infect Dis 1997;104(suppl):30-3.

31 Wimmer ML, Sandmann-Strupp R, Saikku P, et al. Association of chlamydial infection with cerebrovascular disease. Stroke 1996;27:2207-10.

32 Cook PJ, Honeybourne D, Lip GYH, et al. Chlamydia pneumoniae antibody titers are significantly associated with acute stroke and transient cerebral ischemia: the west Birmingham stroke project. Stroke 1998;29:404-10.

33 Cook PJ, Lip GYH, Davies P, et al. Chlamydia pneumoniae antibodies in severe essential hypertension. Hypertension 1998;31:589-94.

34 Maass M, Gieffers J. Cardiovascular disease risk from prior Chlamydia pneumoniae infection can be related to certain antigens recognized in the immunoblot profile. F Infect 1997;35:171-6.

35 Laurila A, Bloigu A, Nayha S, et al. Chronic Chlamydia pneumoniae infection is associated with a serum lipid profile known to be a risk factor for atherosclerosis. Arterioscler Thromb Vasc Biol 1997;17:2910-13.

36 Ramirez JA. Isolation of Chlamydia pneumoniae from the coronary artery of a patient with coronary atherosclerosis. The Chlamydia pneumoniae/atherosclerosis study group. Ann Intern Med 1996;125:979-82.

37 Jackson LA, Campbell LA, Kuo CC, et al. Isolation of Chlamydia pneumoniae from a carotid endarterectomy Chlamydia pneumoniae from a carotid
specimen. F Infect Dis 1997;176:292-5.

38 Yamashita K, Ouchi K, Shirai M, et al. Distribution of Chlamydia pneumoniae infection in the atherosclerotic carotid artery. Stroke 1998;29:773-8.

39 Godzik KL, O'Brien ER, Wang SK, et al. In vitro susceptibility of human vascular wall cells to infection with Chlamydia pneumoniae. F Clin Microbiol 1995;33:241114.

40 Gaydos CA, Summersgill JT, Sahney NN, et al. Replication of Chlamydia pneumoniae in vitro in human macrophages, endothelial cells, and aortic artery smooth muscle cells. Infect Immun 1996;64:1614-20.

41 Knoebel E, Vijayagopal P, Figueroa JE, et al. In vitro infection of smooth muscle cells by Chlamydia pneumoniae. Infect Immun 1997;65:503-6.

42 Yang ZP, Kuo CC, Grayston JT. Systemic dissemination of Chlamydia pneumoniae following intranasal inoculation in mice. F Infect Dis 1995;171:736-8.

43 Moazed TC, Kuo CC, Grayston JT, et al. Evidence of systemic dissemination of Chlamydia pneumoniae via macrophages in the mouse. F Infect Dis 1998;177:1322-5.

44 Black CM, Perez R. Chlamydia pneumoniae multiplies within human pulmonary macrophages[abstract]. In: Abstracts of the 90th Annual Meeting of the American Society for Microbiology, Anaheim, 1990. Washington: American Society for Microbiology, 1990:80.

45 Jackson LA, Campbell LA, Schmidt RA, Kuo CC, Cappuccio AL, Lee MJ, et al. Specificity of detection of Chlamydia pneumoniae in cardiovascular atheroma: evaluation of the pneumoniae in cardiovascular atheroma: evaluation of the $1785-90$

46 Laitinen K, Laurila A, Pyhala L, et al. Chlamydia pneumoniae infection induces inflammatory changes in the aortas of rabbits. Infect Immun 1997;65:4832-5.

47 Fong IW, Chiu B, Viira E, et al. Rabbit model for Chlamydia pneumoniae infection. $\mathcal{F}$ Clin Microbiol 1997;35:48-52.

48 Moazed TC, Kuo C, Grayston JT, et al. Murine models of Chlamydia pneumoniae infection and atherosclerosis. $\mathcal{f}$ Infect Dis 1997;175:883-90.

49 Fryer RH, Schwobe EP, Woods ML, et al. Chlamydia species infect human vascular endothelial cells and induce procoagulant activity. F Invest Med 1997;45:168-74

50 Hughes C, Maharg P, Rosario P, et al. Possible nosocomial transmission of psittacosis. Infect Control Hosp Epidemiol 1997;18:165-8

51 Verkooyen RP, Sijmons M, Fries E, et al. Widely used, commercially available Chlamydia pneumoniae antigen contaminated with mycoplasma. F Med Microbiol 1997;46:419 24

52 Ossewaarde JM, de Vries A, Bestebroer T, et al. Application of a mycoplasma group-specific PCR for monitoring decontamination of mycoplasma-infected Chlamydia sp. strains. Appl Environ Microbiol 1996;62:328-31.

53 Numazaki K, Ikebe T, Chiba S. Detection of serum antibodies against Chlamydia pneumoniae by ELISA. FEMS Immunol Med Microbiol 1996;14:179-83.

54 Nystrom-Rosander C, Thelin S, Hjelm E, et al. High incidence of Chlamydia pneumoniae in sclerotic heart valves of patients undergoing aortic valve replacement. Scand $\mathcal{F}$ Infect Dis 1997;29:361-5.

55 Maass M, Bartels C, Engel PM, et al. Endovascular presence of viable Chlamydia pneumoniae is a common phenomenon in coronary artery disease. $7 \mathrm{Am}$ Coll Cardiol 1998;31: 827-32.

56 Bobo LD. PCR detection of Chlamydia trachomatis. In: Persing DH, Smith TF, Tenover FC, et al, eds. Diagnostic molecular microbiology: principles and applications.
Washington: ASM Press, 1993:235-41.

57 Campbell LA. PCR detection of Chlamydia pneumoniae. In: Persing DH, Smith TF, Tenover FC, et al, eds. Diagnostic molecular microbiology: principles and applications. Washington: ASM Press, 1993:247-52.

58 Tong CYW, Sillis M. Detection of Chlamydia pneumoniae and Chlamydia psittaci in sputum samples by PCR. $\mathcal{F}$ Clin Pathol 1993;46:313-17. 